\title{
AGRICULTURE
}

\section{STUDY OF QUALITY OF THE IRRIGATION CANALS IN AZERBAIJAN}

\author{
Saida Aliyeva, Nariman Ismayilov, \\ Microbiology Institute of National Academy of Sciences of Azerbaijan, Baku, Azerbaijan
}

DOI: https://doi.org/10.31435/rsglobal_sr/28022019/6364

\section{ARTICLE INFO}

Received 17 December 2018 Accepted 23 February 2019

Published 28 February 2019

\section{KEYWORDS}

river waters; irrigation canals; soil pollution; phytotoxicity of waters and soils; purification.

\begin{abstract}
The waters of the Kura River and the irrigation canals are phytotoxic and reduce the percentage of germination of cress-salad and barley seeds in comparison with pure water by $10-12 \%$. After cleaning them on adsorbents, waters lose the phytotoxicity properties. This makes it necessary to solve the problems of cleaning irrigation waters from organic and inorganic pollutants in order to achieve sustainable development of agriculture in the country.
\end{abstract}

Citation: Saida Aliyeva, Nariman Ismayilov. (2019) Study of Quality of the Irrigation Canals in Azerbaijan. Science Review. 2(19). doi: 10.31435/rsglobal_sr/28022019/6364

Copyright: (C) 2019 Saida Aliyeva, Nariman Ismayilov. This is an open-access article distributed under the terms of the Creative Commons Attribution License (CC BY). The use, distribution or reproduction in other forums is permitted, provided the original author(s) or licensor are credited and that the original publication in this journal is cited, in accordance with accepted academic practice. No use, distribution or reproduction is permitted which does not comply with these terms.

Introduction. Due to the favorable climate and soils, Azerbaijan has a comparative advantage in the agricultural sector. However, irrigation is important component for the cost-effective agricultural production.

In Azerbaijan, about 1 million 350 thousand hectares are irrigated territories. Providing farmers with sufficient volumes of irrigation water is a key factor in Azerbaijan's agricultural development strategy until 2020, which provides for a multiple growth in the export potential of the industry.

The need for water in the country is growing from year to year. Therefore, 135 reservoirs with a total volume of $21.5 \mathrm{~km} 3$ were built in the country. The largest reservoirs are the following: Mingachevir reservoir with a volume of million $\mathrm{m} 3$, commissioned in 1953; Shamkir reservoir with a volume of 2,677 million m3, commissioned in 1982; Araz reservoir with a volume of 1,254 million m3, commissioned in 1971; Sarsang reservoir with a volume of 565 million km3, commissioned in 1976.

A number of irrigation canals have been built and are functioning in the country that supply water for irrigation of hundreds of thousands of agricultural fields, on which dozens of crops, including technical ones, are grown.

An irrigation system is regulated by reservoirs functioning in the Republic. Totally there are six reservoirs: Mingachevir, Varvarinsk, Sarsang, Jeyranbatan, Aghstafa, Arpachay. The total length of irrigation canals and collector-drainage systems makes up more than 92 thousand km (Museyibov 2009). The largest main canals were built in the XX century: Samur-Apsheron's (length $182 \mathrm{~km}$, irrigation area is 92 thousand hectares), Upper-Garabagh (172km length, irrigation area 76 thousand hectares), Upper-Shirvan (length $122 \mathrm{~km}$, irrigation area 127 thousand hectares), Canal named after Azizbekov (length $123 \mathrm{~km}$, irrigation area 69 thousand hectares), Main Mil (length $38 \mathrm{~km}$, irrigation area 64 thousand hectares), the main Mughan (length $37 \mathrm{~km}$, irrigation area 68 thousand hectares). The total length of the canals is $47,058 \mathrm{~km}$ (of which approximately $8,580 \mathrm{~km}$ is inter-farm and $38,478 \mathrm{~km}$ is intro-farm canals). Abovementioned canals provide irrigation water to low-level areas in the 
Garabagh, Mil, Mughan, Salyan, Shirvan, Samur-Devechi lowlands. The water-carrying capacity of all canals is about $676.8 \mathrm{~m} 3 / \mathrm{sec}$. The total irrigation area is more than 670 thousand hectares (Museyibov 2009). About 11 billion cubic meters of water are used through canals for irrigation of grazing lands annually. The total area of irrigated land in the republic for 2018 comprises of 1.35 million hectares (Strategic roadmap, 2016).

Waters of river systems are the main sources of irrigation canals. By the degree of pollution, the country's river systems are divided into three categories (Museyibov 2009):

1. Pure rivers - northeastern slopes (except for Kudialchay), the rivers of Lankaran area (except for the river Istisu);

2. Weakly polluted rivers - the main part of the country's river systems;

3. Polluted rivers - Kura, Araz, Okhchuchay, Gabirry, etc.

The Samur-Devechi canal begins from the bordering river Samur. This river as well as other rivers carries a large amount of pollution of organic and inorganic origin (Table 1).

The main irrigation canals of the country are the Upper-Garabagh and the Upper-Shirvan. They are originated from the Mingachavir reservoir, which is filled in with the waters of the Kura River. The waters of this river are heavily polluted by organic contaminants (oil, oil products, pesticides, surface active substances, heavy metals) (Kazibekov, 2002). In the Table 1, there're shown the volumes of organic and inorganic pollutants that are discharged into the Caspian Sea by the waters of the Kura River. However, a significant part of similar contamination falls in the soil cover in lowland regions through a system of irrigation canals, the source of which is also the irrigation waters of the Upper-Garabagh and Upper-Shirvan canals, and others.

Table 1. Contamination of the rivers Kura and Samur (Gul, 2003)

\begin{tabular}{|c|c|c|c|c|c|c|c|c|c|c|}
\hline \multirow{2}{*}{$\begin{array}{c}\text { Water } \\
\text { flow } \\
\mathrm{km}^{3} / \mathrm{year}\end{array}$} & \multicolumn{9}{|c|}{ Tons per annum (1978-1995) } & \multirow{2}{*}{ 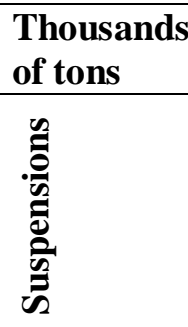 } \\
\hline & $\mathbf{Z}$ & $\frac{n}{0}$ & 苞 & $\overrightarrow{\mathbf{Z}}$ & $\overbrace{Z}^{\sim}$ & $\stackrel{0}{\mathbf{Z}}$ & $\stackrel{+}{0}$ & $\frac{\frac{n}{\pi}}{\sum^{\frac{n}{2}}}$ & 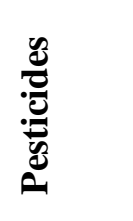 & \\
\hline \multicolumn{11}{|c|}{ Samur } \\
\hline 2.2 & 220 & 4.4 & 39.6 & 902 & 63.8 & 1,078 & 220 & 66.2 & 0.06 & 5,002 \\
\hline \multicolumn{11}{|c|}{ Kura } \\
\hline 18.6 & 1,860 & 167.4 & 632.4 & 2,604 & 8,370 & 31,620 & 1,392 & 2,531 & 1.02 & 14,505 \\
\hline
\end{tabular}

Thus, the waters of irrigation canals have such a qualitative composition that during irrigation, they can have a negative effect on the physical-chemical and biological properties of soils, on the biocenosis, reduce yields and bioaccumulation in agricultural products.

The numerous data ascertain the pollution of the waters of the Kura River and other rivers of Azerbaijan by organic pollutants, including hydrocarbons and phenols (Kazibekov 2002). Our study is aimed to assess the degree of toxicity of the Kura River waters, irrigation canals and soils that were irrigated by the waters of these irrigation canals.

\section{Methods and materials.}

The objects of our research were the waters of the Kura River, Mingachevir reservoir, as well as irrigation canals of Upper-Garabagh, Samur-Apsheron and Upper-Shirvan as well as soils that are irrigated by irrigation canals.

The water samples were taken from the various points of the rivers Kura - Salyan, Neftchala, Zardob, Sabirabad, Mingachevir reservoir, as well as the waters of the Samur-Absheron, UpperGarabagh and Upper-Shirvan canals (from the catchment area) in August 2017. Each sample was taken at the distance with the interval every $40-50 \mathrm{~m}$. Several samples were mixed into one sample then. Overall, five samples of the river and canals were selected and transported to the laboratory. The degree of toxicity of the selected water samples was determined.

The soil samples were sampled from the territory that are irrigated by water through the systems of these irrigation canals (Salyan region). Sampling of soils was carried out with the same 
grids (200x200m). Overall, 21 samples were taken. Sampling of soil samples was carried out in accordance with International Standards: ICO / TK "Environmental Management" and EPA-US environmental standards. The time of selection was determined from the consideration that during the entire summer period the soils of this region were irrigated by the waters of irrigation canals.

In the laboratory conditions, soil and water samples were examined for their phytotoxity degree. In the experiments, the seeds of barley and cress-salad (30 seeds each) were used as test cultures. Phytotoxicity of water samples was determined in the Petri dishes, into which the seeds of watercress and barley were placed. Water samples were added to Petri dishes. The duration of the experiment was 21 days. The percentage of sprouted seeds was determined. As a control, seeds soaked with purified tap water.

Phytotoxicity of soils taken from cotton-growing areas was determined by the method of Grodzinsky (Grodzinskiy 1991). In the experiments, barley seeds and watercress seeds were used as test organisms. The oil toxicity index was calculated. The duration of the experiments for all the plant species studied was 17 days. To assess the germination of seeds, the proportion of germinating seeds was counted from the total number of subjects. Seeds that gave rootlets larger than $1 \mathrm{~mm}$ were considered sprouted.

At the same stage, we conducted laboratory studies to reduce the phytotoxicity of waters taken from different points in the Kura River and 3 irrigation canals: Samur-Absheron, Upper-Garabagh and Upper-Shirvan. To this end, water samples were passed through a column filled with adsorbent cotton bend. All these samples were passed twice through an adsorption column filled in with adsorbent in a downward direction by gravity.

The static processing of the results was carried out using Statistics V6.0 for Windows, Excel 2003 software. When assessing the statistical reliability of the mean data obtained, Student's criterion $t$ was used. The representation of the results in the tables is the average standard deviation.

\section{Results and discussion.}

The results of testing of all waters in terms of their phytotoxicity showed that in general and totally, all selected samples of water had certain phytotoxicity and reduced the percentage of germination of cress-salad and barley seeds in comparison with pure water by 10-12\%. At the same time, the results showed that the waters taken from the Upper-Garabagh and Upper-Shirvan canals have a higher toxicity compared to the waters taken from the Samur-Absheron irrigation canal. This can be explained by the fact that the catchment area of the Samur River is much smaller compared to the Kura River, and consequently a correspondingly lower amount of pollutants, which is noticeable when comparing the data presented in the Table 2.

Table 2. Phytotoxicity of waters used for irrigation of agricultural fields

\begin{tabular}{|l|c|c|c|}
\hline \multirow{2}{*}{ Place of water sampling } & Samples' number & \multicolumn{2}{c|}{ Absolute germination of seeds, \% } \\
\cline { 2 - 4 } & & Barley & Cress-salad \\
\hline Mingachevir reservoir & 3 & $89-92$ & $88-91$ \\
\hline Kura river & 3 & $87-88$ & $88-89$ \\
- Zardob & 3 & $83-84$ & $84-85$ \\
- Sabirabad & 3 & $80-82$ & $81-82$ \\
- Salyan & 3 & $79-81$ & $80-81$ \\
- Neftchala & & & \\
\hline Canals: & 3 & & \\
Samur-Absheron & 3 & $92-94$ & $93-94$ \\
Upper-Garabagh & 3 & $87-88$ & $88-89$ \\
Uppe-Shirvan & 3 & $97-99$ & $87-89$ \\
\hline Control (purified water) & & & $97-99$ \\
\hline
\end{tabular}

The results of the studies of phytotoxicity of soil samples taken from territories irrigated by the waters of the Upper-Garabagh canal are shown in the Table 3. The results of the study showed that the average phytotoxicity of all 12 soil samples is varied between $12-13 \%$ that indicates their phytotoxicity. The phytotoxicity related to the fact that the soils in these regions have been irrigated for many years by the waters initially contaminated by the waters from the Mingachevir reservoir 
which is filled in with polluted waters of the Kura River. The results of the study confirm the opinion that, in comparison with other test biological objects show the greatest sensitivity to soil contamination with oil pollutants (Nikitina 2003). Decrease in germination of seeds of higher plants under the impact of hydrocarbons is also shown in the research works of other authors (Dzhambetova 2005). It was found that the content of hydrocarbons in the medium reduces the radish germination, seed germination in coniferous wood plants (Donets 2009).

Table 3. Phytotoxicity of soils selected from territories irrigated by the waters of the UpperGarabagh canal

\begin{tabular}{|l|c|c|c|}
\hline \multirow{2}{*}{ Place of water sampling } & Samples' number & \multicolumn{2}{|c|}{ Absolute germination of seeds, \% } \\
\cline { 2 - 4 } & & Barley & Cress-salad \\
\hline - Zardod & 3 & $85-86$ & $86-88$ \\
- Sabirabad & 3 & $82-83$ & $84-85$ \\
- Salyan & 3 & $80-82$ & $80-82$ \\
\hline Control (purified water) & 3 & $79-81$ & $79-81$ \\
\hline
\end{tabular}

The results of experiments to reduce the phytotoxicity of waters showed that under dynamic conditions, the water purification has such efficiency that their phytotoxicity has significantly decreased and, in these indices, approached those with pure water (Table 4).

Table 4. Phytotoxicity of waters purified by adsorbents under dynamic conditions

\begin{tabular}{|l|c|c|c|}
\hline \multicolumn{1}{|c|}{ Place of water sampling } & Samples' number & \multicolumn{2}{c|}{ Absolute germination of seeds, \% } \\
\cline { 2 - 4 } & & Barley & Cress-salad \\
\hline Mingachevir reservoir & 3 & $95-97$ & $96-98$ \\
\hline Kura river & 3 & $97-98$ & \\
- Zardob & 3 & $96-97$ & $98-99$ \\
- Sabirabad $\quad$ Salyan & 3 & $97-98$ & $96-97$ \\
- Neftchala & 3 & $96-97$ & $97-98$ \\
\hline Canals: & 3 & & $96-98$ \\
Samur-Absheron & 3 & $97-98$ & \\
Upper-Garabagh & 3 & $97-98$ & $97-98$ \\
Upper-Shirvan & 3 & $96-97$ & $96-98$ \\
\hline Control (purified water) & & $97-99$ & $97-98$ \\
\hline
\end{tabular}

The results of the study indicate that the waters of the Kura River as well as the irrigation waters of all irrigation canals are phytotoxic and potentially increase the phytotoxicity of soils that are irrigated by these waters. In addition, it was shown that after cleaning these polluted waters via adsorbents, the waters practically lose their phytotoxicity.

The obtained results make it necessary to solve the actual ecological problem as water purification of the Upper-Garabagh and Upper-Shirvan canals, from polluting substances using modern biotechnologies to prevent pollution of irrigation waters and soil cover of the country that can be of decisive importance for the production of ecologically clean agricultural products.

Conclusions. The results of research on the quality of irrigation waters clearly bring to the forefront a strategically important problem - cleaning irrigation water from organic and inorganic contaminants that reduce yields and have a negative impact on the biological and physical-chemical properties of soils in order to develop and improve the irrigation system as necessary part of the transition to ecological farming. 


\section{REFERENCES}

1. Grodzinskiy A.M. 1991 Allelopathy of plants and soil fatigue. Kiev Naukova Dumka, pp. 429.

2. Gul A.K. 2003 Caspian pollution problems. Baku, pp.70.

3. Dzhambetova P.M., Reutova N.V., Sitnikov M.N. 2005 The Effect of Oil Pollution on Morphological and Cytogenetic Characteristics of Plants. Ecological Genetics, 3(4), 5-10.

4. Donets E.V. 2009 The effect of oil on the germination of seeds of coniferous forest-forming species of woody plants of the Southern Taiga subzone of the Omsk region. PhD thesis's abstract, Omsk, pp.148.

5. Kazibekov N. 2002 Water resources of Azerbaijan, use and protection. Material of International Conference REC Caucasus on Sustainable Water Resources Management in the South Caucasus Region, Tbilisi, Part II, 7-9.

6. Museyibov M.A. 2009 Physical Geography of Azerbaijan. Baku, pp.398.

7. Nikitina E.V. 2003 Toxicological and microbiological aspects of bioremediation of oil sludge - waste from petrochemical production / PhD thesis's abstract, Kazan, pp.19.

8. Strategic roadmap for the production and processing of agricultural products. 2016, pp.177. 